\title{
The Paradox of Water Management Projects in Central Asia: An Institutionalist Perspective
}

\author{
Lioudmila Chatalova, Nodir Djanibekov *, Taras Gagalyuk and Vladislav Valentinov \\ Leibniz Institute of Agricultural Development in Transition Economies (IAMO), Theodor-Lieser-Str. 2, \\ Halle (Saale) 06120, Germany; chatalova@iamo.de (L.C.); gagalyuk@iamo.de (T.G.); valentinov@iamo.de (V.V.) \\ * Correspondence: djanibekov@iamo.de; Tel.: +49-345-2928128
}

Academic Editors: Ronny Berndtsson and Kamshat Tussupova

Received: 6 March 2017; Accepted: 18 April 2017; Published: 24 April 2017

\begin{abstract}
After the disintegration of the Soviet Union, the Central Asian countries have been faced with numerous development challenges in agriculture, especially those related to water use. Well-intentioned foreign donors and development agencies have stepped in to support local farmers, research centers, and public authorities in devising innovative solutions. Yet, development aid projects have borne fruit only partially. Paradoxically, innovative and apparently useful technologies proposed by foreign donors have rarely and only partially succeeded in taking root in the local institutional contexts. To explain this paradox, this paper draws on the institutional approach which shows the possibility of technological innovations being encapsulated by dysfunctional institutions. Reviewing recent studies of water-related projects in Central Asia, the paper shows this encapsulation to be at the core of the development project failures pervasive both in the Soviet period and today. If the concept of encapsulation is valid, then the current development efforts can be made more effective by detecting and counteracting the structures of vested interest on the part of all the actors involved, such as foreign donors, public authorities, research centers and local farmers.
\end{abstract}

Keywords: Central Asia; water use; development projects; innovation adoption; institutionalist dichotomy; Veblen; transition economy

\section{Introduction}

The water resources in Central Asia have experienced a long history of mismanagement, which is well exemplified by the scale of the Aral Sea disaster. Since the 1990s, water resource management in Central Asia has become the object of foreign aid via development projects. Despite extensive research, the effects of this aid on resolving water conflicts, and economic development more generally, remain highly controversial [1,2]. The contention of these papers is that at least some elements of this dilemma can be traced back to the Dutch Disease, aid volatility, and political deterioration, each of which is known to lower the effectiveness of foreign aid [3]. According to Zhupankin et al. [4], "the uneven spatial distribution and complex pattern of transboundary water sources with contrasting national water needs have created an intricate water dilemma" [5,6]. In general, donor countries apply two approaches to make their aid more effective [3]. For one, the donors may attempt to change the behavior of recipient governments by imposing policy conditionality in exchange of aid. Second, the implementation of project-based aid may bypass the government's authority. Both approaches led to similarly disappointing results, without adding much clarity to the issue of whether development aid advances institutional quality and political reforms in the recipient countries. If the effect of aid on economic growth is positive, it probably originates from the development of democratic institutions which mobilize financial and human resources for the necessary political and economic reforms [7]. However, it remains entirely possible for international aid to undermine institutional quality and political reforms, as well as to increase rent seeking [8]. 
For example, as a part of international aid, the Green Revolution in the second half of the last century inspired numerous explanations of the determinants of innovation adoption in agriculture [9]. The agricultural sector was seen to be equipped with several innovation channels such as agricultural practices (learning-by-doing), outsourcing from other industries, and scientific research. It was found that agricultural innovations tended to be produced through public or private research outside of agriculture and then imported for adaptation [10]. A further finding was that the innovations brought from outside often required substantial public and private investments for fine-tuning to local circumstances, and to the specific needs of end users [11]. Numerous present-day water management projects in Central Asia exhibit similar patterns [12-14].

In implementing agricultural innovation programs, the governments of adopting countries pursued several strategies. The promotion of information exchange through extension programs was joined with an active agricultural policy stance. The intended policy measures included subsidies for innovation adoption and the development of complementary infrastructure, first of all related to water; a certain role was likewise played by unintended policies such as commodity price manipulation [15]. These policies drew the attention of social scientists and agricultural economists to agricultural innovation diffusion, and especially to the factors and constraints influencing the individual adoption behavior [9]. Recognizing that the microeconomic aspects of innovation and development aid are influenced by the macro-environment, scholars have analyzed the aggregate diffusion patterns as well as the impact of infrastructure, environment, climate and related factors on the adoption process. The main thrust of the agricultural economics literature that has thus emerged is that innovations do not occur randomly. Rather, the nature and rate of the adoption process are contingent on incentives, public policies, and the pro-activeness of the private sector [15].

Development aid and innovation activity are highly relevant for the transition economies of the post-socialist block, and especially the Central Asian countries, where the transformation of the command economy into a market-oriented one resulted in drastic economic and political shocks, declining economic performance and rising inequality, as well as tensions over water use. For these countries, the primary aim of the development aid was to facilitate the replacement of central planning by more egalitarian models based on free markets and institutional development [16,17]. A notable feature of these countries is not only the strong dependence of agriculture on innovations and technical progress, but also the transfer of innovation responsibilities from strong central actors, such as ministries, to the newly emerged agricultural producers. This transfer was supported by access to international aid, with the outcome that both the new governments and the newly-emerged producers lacked financial means and capacities for investing in R\&D projects, thereby reinforcing the influence of donors' aid.

It is common knowledge that many, if not all, development aid and innovation projects in these countries can be considered to be partly successful in some respects, both in Soviet times and afterwards. While the relative backwardness of technological standards of a command economy can be partially blamed for the failure of innovation diffusion, the transition to a market economy did not crank up the adoption of new technologies either. There is thus no reason to assume that market institutions are by definition more effective in incentivizing innovation adoption than socialist ones. This lack of success constitutes the main paradox motivating the present inquiry. In examining the influence of adopters' characteristics on the outcome of the development aid and innovation projects, the bulk of the available literature does not seem to be informed by a holistic perspective sensitive to the broader natural, social, and economic context. In recognition of a complex policy problem in persistent project failures, the present paper is aimed at filling this gap by exploring the way in which the features of the institutional environment systematically translate into conflicts of interests for various actors involved in the implementation of the water management projects. It contends that a diagnostic analysis of the unwanted outcomes of innovation adoption necessarily means addressing the institutional underpinnings of an economy on which market transactions and individual interactions rest. The paper's theoretical strategy is to revisit the popular new institutional 
economics accounts of project failures in the light of an earlier scholarly tradition of the classical, or original, institutionalist economics going back to Thorstein Veblen. Using the example of the post-socialist Central Asian settings, the Veblenian idea of the "institutionalist dichotomy", i.e., the discrepancy between institutions and technology, is shown to provide crucial insights into the paradox of development project failures.

Adopting the lens of the institutionalist dichotomy draws attention to the patterns of so-called "institutional encapsulation" occurring at the level of various stakeholders at the different phases of project implementation, such as local administration, central government, researchers and farmers. We show this encapsulation to be primarily responsible for preventing technological innovations from unfolding to their full potential for the enhancement of social wellbeing. In doing so, we look beyond the more familiar reasons of project failures, such as those related to land tenure, centralized decision making, lack of policy integration, short horizons of policymakers, lack of economic incentives for innovation, and failures of the private extension sector.

\section{American Institutionalism: A Brief Introduction}

The dichotomy between institutions and technology is a key theme in the writings of Thorstein Veblen, the founding father of the American tradition of institutional economics. Witnessing the rise of business oligarchy in American society at the turn of the twentieth century, Veblen discerned the need to draw a clear distinction between technology and the institutions controlling it. While technology holds the potential to solve many urgent societal problems, such as hunger, hygiene, or healthcare, the reigning economic and political institutions hold it back as they are primarily geared to protecting the self-interest of business oligarchy, or in Veblen's terminology "vested interests". If technology fails to address societal problems, it must have been institutionally "encapsulated" by dysfunctional institutions. A good example of what Veblen called "imbecile" institutions is the agricultural policy of the destruction of foodstuffs which could alleviate the persevering hunger problems. Veblen concluded that bringing technology in line with community wellbeing, i.e., with "instrumental value", calls for changes in the dominant institutions. While these changes are notoriously difficult to realize, they present the crucial channel translating technological innovations into sustainable improvements in community wellbeing. This argument seems to shed considerable light on pervasive failures of contemporary development aid projects, both in general and in Central Asia in particular.

Subsequent institutionalists, such as Ayres [18,19], Foster [20], and Bush [21,22], drew on the Veblenian dichotomy in order to advance a dual characterization of institutions in terms of their "instrumental" and "ceremonial" values [23]. While purely instrumental institutions present efficiency-driven problem-solving devices, ceremonial institutions rest on prescriptive norms that aim to preserve power and status differentials. Accordingly, ceremonial institutions tend to impede technological innovations as well as to replace critical scrutiny and scientific inquiry by the "logic of adequacy" [22] (p. 1080) or "sufficient reason" [24] (p. 623), meaning the conformity of technological development with the extant rules and ideologies [19] (p. 30), [22] (p. 1094).

Institutionalists characterize the relationship between instrumental and ceremonial values as asymmetrical. This means that the strong logic of instrumental efficiency cannot rationalize ceremonial behavior [22] (p. 1083), while the less demanding logic of ceremonial adequacy can subsume instrumental behavior. In the latter case, instrumental behavior becomes enclosed, or "encapsulated", by ceremonially dominated institutions [22] (p. 1082). Whereas encapsulation per se does not necessarily preclude the realization of instrumental value [25] (p. 187), it does imply that the extant institutions are permissive of the technological progress only as long as the latter reinforces the extant relations of power and "institutional dominance". Consequently, modern institutionalists take institutional change to be truly progressive only if it involves the weakening of encapsulation and of the concomitant institutional dominance, by promoting the diffusion of newly learned instrumental behavior throughout the community [26-28]. 
While the ideas of encapsulation and institutional dominance present refreshing perspectives on why technology adoption in Central Asia has failed to meet optimistic expectations, the concept of instrumental value has been subject to much debate and contestation (e.g., [29,30]). It is indeed difficult to compare the Soviet and transitional periods of technology adoption in Central Asia in terms of the realization of instrumental value. A more pertinent question seems to be related to disentangling the specific causal mechanisms of encapsulation and institutional dominance that led to slacks in technology adoption. This more practical question draws attention to the legacy of John R. Commons, another seminal institutionalist writer, who found the Veblenian dichotomy too pessimistic and overly dismissive of the possibility of genuine institutional reform. One of the central tenets of Commons' institutional economics is that tentative resolutions of conflicts of interest are mediated by deliberate changes in working rules, which create "a workable mutuality and orderly expectation of property and liberty" [31] (p. 92), [32]. Furthermore, Commons embraced a "volitional" conception of economic life $[33,34]$. This means that economic values and activities are determined not by physical facts, natural laws, or spontaneous market forces but by human volition primarily pertaining to the desire of authoritative agents to resolve their conflicts and disputes through the adoption of working rules $[34,35]$. Economic outcomes, such as transactions and technology adoption behaviors, present enactments of these rules.

Commons made use of a tangled web of interrelated concepts such as "institutional adjustment", "artificial selection", and "negotiational psychology", among many others. Institutional adjustment is made necessary by the unanticipated consequences inevitably resulting from the previously adopted working rules [35] (p. 71), while the notion of artificial selection drives home the point that the socio-economic life unfolds as a result of purposeful activities of citizens and authoritative agents who are "looking to the future" [34]. The theory of negotiational psychology refers to a model of human behavior that goes far beyond the neoclassical logic of constrained maximization $[35,36]$. The distinct normative standard corresponding to these concepts is not instrumental value but "reasonable value", which is generally concerned with "whether one is giving up a larger share, and the other is therefore receiving a larger share of the social output than is 'reasonable'" [31] (p. 333). Attaining reasonable value is not subject to any inexorable logic of technological development a la Ayres [37]; it is a matter of the volitional design of institutions judged to be workable at a specific time for a specific task. Reasonable value is inherently negotiational. This is why "Reason differs from Reasonableness. Man is not a rational being, as the Eighteenth Century thought; he is a being of stupidity, passion, and ignorance, as Malthus thought. Hence Reasonable Value contains a large amount of stupidity, passion, and mistake" [31] (p. 682). The latter characteristics notwithstanding, reasonable value remains practically feasible, whereas the Veblenian subordination of instrumental value to ceremonial value is a foregone conclusion, at least in capitalist societies.

If the institutionalism of Commons is used as a source of inspiration, then a diagnostic analysis of technology adoption and of water management projects in Central Asia must involve identifying the relevant authoritative agents, understanding their goals, and figuring out why these goals were discordant. It is noteworthy that the systems-theoretic scholarship has long been aware that goal-setting and goal-seeking are precarious activities inasmuch as they are bound to generate side-effects and unanticipated consequences that are likely to be ignored [38,39]. It seems that critique of the disregard of consequences presents a common ground for normative paradigms of institutionalism, instrumental value and reasonable value. In developing a systems-theoretic account of the instrumental value paradigm, Valentinov $[26,40]$ showed the disregard of consequences to be symptomatic of ceremonial value. If the ignored consequences are publicly perceived as important, then a Commonsian perspective would judge the underlying institutions to be unreasonable and needful of reform. The overall institutionalist lesson is this: there is no way for technology to be diffused and adopted other than through institutional channels which are framed by the volitional goal-setting and goal-seeking activities of authoritative agents. Accordingly, the effectiveness of technology adoption crucially hinges on the way the side-effects and ignored consequences of these activities are dealt with. This depends 
on the permissiveness of institutions. What needs to be added to the idea of permissiveness is the insight that reasonable technology adoption does not mean maximum adoption, as suggested by the institutionalist "principle of minimal dislocation" [22] (p. 1106).

\section{Encapsulation and Institutional Dominance in Water Use}

\subsection{The Soviet Period}

Before the breakup of the Soviet Union in 1991, innovation diffusion in the agriculture of the Central Asian republics used to be planned and controlled by a strong central actor, namely ministries in Moscow with local representative branches. The state-regulated promotion of technological innovations, which we term here the Soviet model, involved assessment of the demand for specific innovations and their further testing and diffusion according to the Party's priorities (Figure 1). In this ruling-down hierarchical model, a strong focus was placed on the existence of national and local research centers and their coordination through the centrally issued tasks, norms, plans and orders. State and collective farms cooperated with the national research centers on identifying a feasible set of technologies to be tested for implementation. Central to the Soviet model was the operation of a central actor overseeing the activities of other actors. In a Veblenian interpretation, this central actor constituted the key source of ceremonial encapsulation of technological development. This encapsulation was bound to suppress the interests of the overseen actors. On a Commonsian interpretation, this agent wielded unreasonable power.

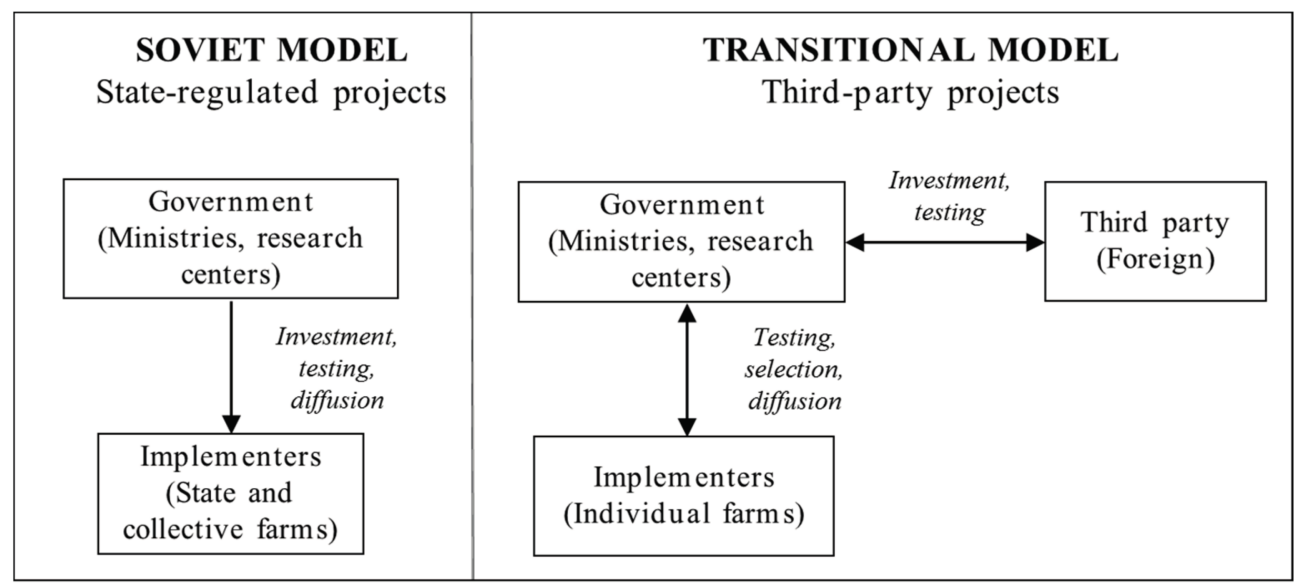

Figure 1. Models of innovation projects.

The literature documenting the Soviet model of innovation diffusion identifies three main reasons for the poor track record of innovation projects: labor abundance [41], vested interest of kolkhoz managers [42], and the mismatch of state plans with local conditions, including cultural barriers [43,44]. On reflection, each of these reasons arises out of the ceremonial encapsulation suggested above. According to Dearden et al. [45], a key obstacle to the adoption of innovations in hierarchies was not costs associated with innovation development, but the cost of the institutional environment enabling the adoption.

Pomfret's [41] study of the slow and restricted cotton mechanization in Soviet Central Asia is a case in point. He shows that the Soviet central planners were motivated by the ceremonial and invidious goal of outpacing the technological development of the United States. Given this goal, it is unsurprising that planners' efforts were thwarted by the great resistance of kolkhoz farmers who were responsible for the implementation of technical improvements. The main reason for this resistance was not the incompetence of managers or planners, but rather the abundance of labor. Additionally depressed by regular levies of students and urban workers, the low labor cost made hand-picking more economical compared to the labor-saving mechanization. As a result, kolkhoz managers preferred 
to leave the available machine stock idle. Furthermore, active engagement of students and casual workers disrupted industrial production and education [41]. According to Pomfret, "[ $t]$ he true cost of state-directed diffusion was not that planners failed to speed up diffusion, but that they did it too far ahead of its time" [41] (p. 186). This finding shows that Veblen was right on at least two counts. First, it demonstrates that successful adoption of technology is impossible if it is not institutionally secured. Second, it shows progressive institutional change to be unlikely if it is driven by ceremonial or invidious considerations. At the same time, Commons would stress that institutions cannot be changed unless this is desired by the authoritative agents, who must hold the appropriate beliefs.

Another recent study of the persistence of manual cotton picking in Uzbekistan during the Soviet era likewise points out dysfunctional institutions hindering the adoption of new technology [42]. Keller describes the top-down institutional reforms initiated by Soviet planners, including the state-ordered consolidation of farms, a new labor organization, wage reform, and the setting up of regional economic councils. For one, these councils turned out to "undercut the authority of central ministries without providing sufficient resources to allow local governments to meet their new responsibilities" [42]. As a result, both the ministries and local councils diverted funds to unintended uses. Secondly, the newly introduced cash wages were perceived by farmers as too low relative to the growing farm income and productivity, thus discouraging them from adopting costly innovations. Thirdly, unemployment among the growing rural population made manual harvesting cheaper and more cost effective than mechanical harvesting. Finally, in view of the steadily increasing output quotas for raw cotton, "the pressure to modernize in a cultural sense dwindled" as well [42]. Keller concludes that cultural values and patriarchy — or ceremonial dominance in Veblen's words- "were and are factors creating Uzbekistan's dependence on manual labour" [42], and impeding the introduction of new technology. Keller thus backs up Pomfret's observations by showing that the ceremonial top-down reforms in the institutional structure would be in vain unless supported by appropriate and sufficient technologies.

Similar top-down actions that suppressed the instrumental aspects of technological innovation in agriculture were undertaken in Soviet academia. Cocks [43] notes that Soviet science and technology policy was reoriented in the late 1960s away from the creation of new technologies toward technology application. While trying to control research activities, this policy increased the organizational dissociation between research and development actors, leading to deficiencies in organizational structure, planning, management and motivation [43]. These deficiencies further aggravated the mismatch between technology and physical agricultural and other local conditions, thus causing not only the degradation of soil and harvest quality but also the hostility of local stakeholders. It therefore came as no surprise that the collapse of the Soviet Union led to the complete abandonment not only of cotton mechanization but also of the production of cotton harvesters.

Gleason's study [44] of the process of institutional redesign of centrally administered policies in view of the emerging sovereign legal structures of the Central Asian states presents another illustration of the cultural barriers that have arisen in a number of disputes between local governments and the Soviet Central apparatus in the Central Asian water management crisis. As Gleason reports, the failure to acknowledge cultural values such as traditional reverence for water obstructed the smooth privatization of water rights. Another problematic cultural value was that water could not be accepted as a saleable commodity that had to be economized. To follow the innovation plans, the Soviet administration either adopted superficial changes via "pseudo-innovations" or claimed nonexistent cases of adoption [46] (p. 375).

Generally speaking, the breakup of the Soviet Union has radically changed the institutional environment in which the former Central Asian republics operated. First, the decentralization of the Soviet system of policymaking necessitated reformulated plans for the newly-emerged economies, namely Kazakhstan, Kyrgyzstan, Tajikistan, Turkmenistan and Uzbekistan. Those plans included the reorientation and modernization of agriculture towards food self-sufficiency, mainly via import substitution of grains and livestock products. Second, decentralization put a halt to the inflows from the central financial pool, thereby setting limits for budget expenditures. This political and 
economic reshuffling has turned on its head not only policymaking, but also the organization of the research landscape. Most remarkably, the processes of innovation adoption and diffusion were no longer hierarchical.

While the post-Soviet Central Asian research community had long experience of experimenting and learning in applied science (e.g., in the development of agricultural machinery, irrigation infrastructure, and crop management), it was ill-prepared to deal with the new decentralized environment. With the onset of decentralization, this community was confronted with novel challenges including, but not limited to, water supply instability, progressing climate change, and degradation of agricultural lands. Each of these required urgent solutions in the midst of the turbulent process of the fragmentation of centrally-operated and target-oriented collective farms into decentralized private decision-making units. The latter faced similar challenges, but were unprepared to deal with them individually. The widening knowledge and technology gap called for the participation of a competent third party that would complement its expertise with that of the local actors, primarily government and research centers. Participation of the third party in the promotion of agricultural innovations constitutes the key feature of the Transitional model of innovation diffusion. In contrast to the Soviet model, the Transitional model was explicitly geared to the level of newly-introduced individual farms that badly lacked both experience and financial resources (Figure 1).

\subsection{The Transitional Period}

As the new governments and newly-emerged individual farms lacked financial means to invest into projects, the Transitional model incorporated an international donor agency as a third party. The international donor would facilitate the transfer of innovation responsibilities from ministries and related institutions to agricultural producers. Such interaction between governments and donors also incorporated the fine-tuning of innovations to local circumstances, and to the specific needs of end users. Part of these interactions came in the form of certain policy conditionality imposed by donors on recepient governments to promote instituional environments that would enable innovation adoption and diffusion. The Transitional model is, thus, more contested and negotiational.

An institutionalist analysis of development aid draws attention to the patterns and problems of institutional encapsulation of technology. In the Soviet period, encapsulation could be clearly attributed to the central planners who were steering the processes of innovation diffusion. Being inherently conservative, central planners were not at all interested in lowering the extent of institutional dominance and in the spreading of instrumental habits of thought that might ultimately call into question the legitimacy of extant political power [47]. The important institutionalist point is that the third party implicated in the Transitional model of innovation diffusion likewise presents an inevitable source of encapsulation. The third party is typically represented by foreign and international donor agencies that import new rules and visions of the implementation of innovation projects. True, the nature of encapsulation within the Transitional model differed markedly from that in the Soviet model. Most importantly, the Transitional model encompassed a platform in which the interests of involved actors could be negotiated in such a way that the role of local farms was strengthened. Also noteworthy is the favorable impact of the third party's funds and investments on strengthening the capacity of national research centers. Yet, the third party acquired considerable political influence over the innovation diffusion processes, thus disappointing hopes that the Transitional model would resolve problems of encapsulation and institutional dominance. If such hopes are to be realistic, they must pertain to the reasonable reconciliation of interests of all the authoritative agents involved, along the lines of John R. Commons' reasonable value theory.

Consider a recent study of the implementation of innovative irrigation technologies by Water Users Associations (WUAs) in the Ferghana Valley, shared by Kyrgyzstan, Tajikistan and Uzbekistan [13]. The third party commendably invested non-trivial resources into addressing the salient problem of water and land use in provinces suffering from land degradation and water scarcity. Furthermore, in contrast to the state-directed innovation projects, WUAs' traditional focus on efficiency 
was no longer "purely technical" but rather based on "a more human and organization centered paradigm" [13] (p. 1). Yet, Kazbekov et al. [13] discerned that "the interests and experience of temporal project owners" led to project uncertainty and thus to the failure of the project's technical upgrade [13] (p. 9). Encapsulation and institutional dominance were evidenced by the third party's interference with the local owners' interests which turned out to play a non-negligible role. The authors have discovered that if the third parties influence these interests, existing project knowledge and experience, i.e., "project memory", might get lost or overruled when transferred to new owners. Even if the roles of project partners are legally fixed, "the individual interest might shift power balances between internal project owners and therefore might determine changes of project objectives and implementation procedures" [13] (p. 8).

Yamaswari et al. [48] report a similar experience with a water management project conducted from 2001 to 2012 in the Ferghana Valley. The project's goal was to establish long-term transboundary water cooperation between the riparian states in order to improve water management in the Syr Darja basin. Despite favorable economic conditions, and close collaboration with donors, the project suffered significant delays in the planning phase. According to the authors, similar problems occurred with an earlier water management project that was launched in 1998 by the United Nations Special Program for the Economies in Central Asia (SPECA) in the same region. Based on their perceptive analysis of project documents and implementer experience, the authors identify project rigidity, especially in the planning phase, as the major hindrance to effective project implementation. They conclude that unless a project is flexible, and hence not excessively encapsulated by rigid stratified structures of status and privilege, it will be incapable of adapting "to the constantly changing environment" [48] (p. 16).

Oberkircher [12] inquires into the reasons why water saving technologies developed by academic research have been seldom adopted by farmers in the Khorezm province of Uzbekistan. In line with the dichotomous view of technology and institutions, she identifies reasons of an institutional nature-most importantly the divergence between the discursive constructions and local experiences of water scarcity (cf. [49]). She argues that the researchers' understanding of technology is necessarily socially constructed (cf. $[47,50]$ ) and embedded in their own lifeworld which gives prominence to the issues of inefficiency and unsustainability of water use, especially in the long term. In contrast, farmers experience water scarcity as a lack of technical, organizational, or sociopolitical control over water [12]. Farmers' water use decisions reflect their pragmatic short-term planning priorities rather than long-term sustainability concerns, not least because of political risks of losing their land.

Given that farmers tend to decouple their water use practices from land issues, Oberkircher [12] argues that an intimate understanding of institutional structures of scholarly activity is essential for identifying workable solutions to water scarcity in Uzbekistan. No less remarkable is her argument that the technologies developed to improve water use efficiency would have a better chance of being adopted if the (seemingly ceremonial) state control could be loosened and land tenure secured [12]. "In this process, farmers should not only be regarded as the recipients of scientifically produced knowledge far from their reality, but should be included in the problem-definition process as well as in the search for adequate solutions" [12] (p. 1283). Otherwise, farmers would respond "to unanticipated advances in the arts and sciences ... by attempting to minimize the impact of the technological innovation on the existing habits of thought and behavior" [22] (p. 1094). In the Veblenian framework, this recommendation gives expression to the principle of minimal dislocation mentioned above.

In another study, Oberkircher and Hornidge [51] analyze how farmers' perceptions of water management influence water conservation in the Amu Darya lowlands of Uzbekistan. The authors show the seemingly instrumental behavior of water conservation to be impeded by ceremonial institutions such as the symbolic or religious values of access to water, as well as by farmers' beliefs in the state's responsibility for water management. This finding is in line with John Dewey's [52] conclusion that customs supply the standards for human activities and interactions. As Bush put it, "[ $t]$ hose patterns of behavior perceived to be vital to the survival of the community are the most carefully prescribed and carry the heaviest sanctions" [22] (p. 1077). According to Oberkircher and 
Hornidge [51], lack of knowledge of the causal chains involved in environmental processes presents the central barrier to effective water conservation. This is why they promote environmental education, along with the decentralization of water storages. Another advantage of environmental education seems to be its conformity with the principle of minimal dislocation. For "while many agricultural topics are politically sensitive, general teaching about environmental processes and water saving on the local level would be unlikely to create problems with authorities" [51] (p. 417).

Examining the options for improving system-level water use efficiency in the Khorezm region of Uzbekistan, Bekchanov et al. [53] point out the availability of advanced technological solutions involving laser-guided land leveling. Here, however, the technology seems to be too advanced to comply with the principle of minimal dislocation. The authors document farmers' reluctance to adopt the extant best practices, and explain it in terms of the high initial investment costs which are hardly acceptable for farmers suffering not only from low income but also from a lack of the necessary knowledge. In line with the principle of minimal dislocation, the authors suggest giving priority to those solutions that are less costly, even if less technologically sophisticated. They argue that the widespread adoption of new technologies can only be sustainable if the rates of institutional and technological change are balanced.

The above studies concur in acknowledging that most innovations introduced or supported by foreign donor organizations performed well in the field experimental conditions and seemed to be economically feasible. Yet, despite the interest of all the stakeholders to put the innovations into practice, their successful adoption has been minimal. The institutionalist perspective suggests that the reasons for project failure are not dissimilar from those that were endemic to the Soviet model of agricultural innovation. Both groups of reasons involve excessive institutional encapsulation manifesting itself in the costliness of efficient technologies, vested interests of stakeholders, and poor coordination between them.

\section{Discussion}

Their wide-ranging differences notwithstanding, the Soviet and Transitional models of agricultural innovation exhibit common bottlenecks related to the institutional encapsulation of novel technologies. These bottlenecks present the essential sociocultural barrier to successful innovation diffusion. In Soviet times, this barrier was exemplified, among other things, by rural patriarchic values that sustained manual cotton-picking [42]; in the transition period, a similar pattern is discernible with beliefs in water's sacredness hindering water-saving by local farmers [51]. Interestingly, the institutionalist approach shows ceremonial values and institutions to be especially resilient in "densely populated regions with strong preindustrial cultures" [18,54]. It is indeed the case that the transitional projects have been implemented in the Fergana Valley regions-the three most densely populated regions of Uzbekistan $[55,56]$. To fully appreciate this point, recall that Uzbekistan is a very densely populated country. Howard and Howard [57] mention that the average population density was 67.5 inhabitants per square kilometer in 2012 reaching 460 inhabitants per square kilometer in the Ferghana Valley regions [55] compared with a ratio of 6.3 inhabitants per square kilometer in neighboring Kazakhstan. Additionally, according to the World Bank Group [58], two thirds of the Uzbek population live in rural areas.

The encapsulation present in both innovation models is evidenced by a high degree of centralization of decision making in the hands of the government. In fact, one is tempted to compare the new requirement toward "efficient land use" in the transition period with the Soviet-type production maximization plans. By undermining the security of land tenure, this requirement discourages farmers from long-term investments. Even though the stakeholders are well aware of the usefulness of new technology [13], public policy forces them to stick to short-term planning horizons and to consider themselves as mere temporary managers of the state land. Similarly, the export orientation of cotton persists at the cost of the development of a domestic cotton sector or diversification towards high value crops. 
In both models, project stakeholders may hold inadequate views of the resources needed for successful project implementation. The problem of divergence between discursive constructions and local understandings of resource endowments is germane here [49]. In Pomfret's [41] study of the Soviet model, project planners failed to recognize the factor of abundant labor and attempted to mechanize cotton harvesting "far ahead of its time". The transitional context, in contrast, does acknowledge the importance of human capital at the project planning stage. Yet, the decentralization promoted by this model has turned out to be an ineffective tool for innovation diffusion if the responsibilities for project implementation are shifted down to local authorities who are not in possession of the required skills and competences. In fact, the dependence of the rate of development on the level of education of the community was stressed by the institutionalist Clarence Ayres [18] long ago.

A related prerequisite for successful project implementation is the continual adjustment in many areas such as water supply, rural infrastructure, agricultural input industries, and public administration. Especially in the transition period, an action to make such pervasive changes requires an agreement among project parties over rules and rights that need to be adopted. Time-consuming discussions and contestations over the parties' purposes and needs are characteristic of this process, but what is more striking is that the ultimate agreement that "emerges from these layers of contestation appears to stand only the smallest of chances of providing meaningful guidance to those who would somehow 'manage' nature" [34]. Yamaswari et al. [48] are, thus, probably right in pointing out that delays in this adjustment process translate into project rigidity in the planning and implementation phases.

The institutionalist approach emphasizes the interrelation between institutional reform and the social construction of resource endowments. Institutional reforms occupy center stage, for example, in the seminal analysis of Acemoglu et al. [59] who traced the rapid economic growth in many European countries back to the effects of the French revolution, such as the introduction of the civil legal code and equality before the law, the abolition of guilds and the remnants of feudalism, and the undermining of aristocratic privileges. The authors argue that these reforms paved the way for the rise of German modernity. Kopsidis and Bromley [60] take issue with Acemoglu et al.'s [59] "big-bang" approach, underscoring instead the role of coal production in the west and northwest regions of Germany as the essential resource basis for modernization. It does not seem far-fetched to conjecture that, in advancing Central Asian agriculture, the Soviet rulers sought to create a similar resource basis. These rulers succeeded in modernizing the irrigation infrastructure in technological terms and in making cotton production the backbone of the regional economy, but they failed in the institutional respect [61]. The strong preference for a top-down approach closed the door on any effective innovation diffusion from the bottom up.

Devising his four development principles, Ayres [18] emphasized that any society endeavoring to benefit from innovations has to discard past-oriented symbolic or ritualistic values in favor of scientifically based arguments. This would alter this society's evolutionary path "through the application of collective intelligence, or through conscious search for useful innovations and alternatives" [54]. Searching for alternative ways of development, both the Soviet and Transitional models seem to have failed to make full and sustainable use of the collective intelligence of the stakeholders involved. Strong ceremonial controls rendered the available resources either excessively abundant or excessively scarce. Furthermore, rigid institutional structures block the emergence of efficient redistributive mechanisms that would compensate for the institutional dislocations caused by technological progress [62]. For example, the use of water-saving technologies by local farmers in the Transitional model can weaken the state administration's influence over water distribution such that it can consequently withholds it support, thus making these technologies institutionally unsustainable. Despite this outcome, such a project can still be considered as successful as it might fulfill the projected number of trained farmers and of new adopted laws, although the project's ultimate result is the less-efficient status quo.

In light of the shortcomings of the two models of agricultural innovations, technology transfer can be only effective if informed by the assessment of available resource endowments, including 
the absorptive capacity of the recipients, as well as by the analysis of stakeholder's vested interests and the concomitant degree of institutional encapsulation. A challenging task here is not to agree over goals acceptable to all the parties involved but to understand the reasons behind each party's contesting purposes and needs [34]. This assessment has to be undertaken before the decision on project implementation is made. Otherwise, chances are that the completion of projects will mark the return to business as usual on the part of not only government stakeholders and research centers but also farmers, who develop a reluctance for the adoption of new solutions. In the development aid context, the return to business as usual is proof of institutional dominance and encapsulation.

\section{Concluding Remarks}

A remarkable feature of current water use practices in Central Asia is the pervasive failure of innovative and apparently useful technologies to become firmly implanted in the local institutional structures. This feature finds its theoretical explanation in American institutionalism, a school of economic thought that has long been concerned with the precarious relationship between institutions and technology. This approach teaches us that effective technological change requires that institutional innovation be a constant and complimentary activity. Encapsulation occurs if institutional change is stymied by perverse interests-Veblen's ceremonial impediments. In fact, "the most widely recognized evidence of ... ceremonial encapsulation in the standard economics literature is to be found in those studies that report the frustration of the best-laid plans of economic development in less developed countries" [22] (p. 1095), [63-66]. Being primarily interested in patterns of ceremonial encapsulation, the institutionalist approach does not postulate a radical difference in the Soviet and Transitional models of innovation diffusion, and accordingly does not take the latter model to present the ultimate solution to the problems that notoriously plagued the former one. Neither model can avoid the risk of ceremonial encapsulation; the Transitional model however can avoid or minimize it by laying bare the complex structures of vested interests on the part of foreign donors, public authorities, research centers and local farmers, and by allowing these authoritative agents to reach reasonable agreements.

Veblen [47] argued that the rise of progressive technologies may require, as well as promote, sweeping changes in the habitual ways of thinking in the communities concerned. It is inevitable that these changes pose threats to those authoritative individuals who presently enjoy positions of power and privilege. No less important for technological and economic development are the limits on the "capacity to learn the adaptive skills necessary to absorb technological innovation" [22] (p. 1106). Understanding these and other limiting factors of technology adoption calls for more research on the wider institutional repercussions of technology on water use practices in Central Asia. It is our hope that the potential of the institutionalist approach will be put to the fullest possible use to carry this research forward.

Acknowledgments: The publication of this article was funded by the Open Access Fund of the Leibniz Association.

Author Contributions: Lioudmila Chatalova, Vladislav Valentinov and Nodir Djanibekov developed the idea for the paper. Lioudmila Chatalova introduced the institutionalist approach and reviewed the literature on innovation adoption in Central Asia. Nodir Djanibekov described the alternative models of innovation projects, provided his expertise on the region and existing studies, and coordinated the revision process. Taras Gagalyuk contributed to the synthesis of information from literature and wrote the discussion section. Vladislav Valentinov organized the structure of the manuscript, contributed to the overall conceptual development of the paper, and elaborated the institutionalist part of the argument. The authors' names are provided in the alphabetic sequence.

Conflicts of Interest: The authors declare that they have no conflict of interest.

\section{References}

1. Easterly, W.; Levine, R.; Roodman, D. Aid, policies, and growth: Comment. Am. Econ. Rev. 2004, 94, 774-780. [CrossRef]

2. Brückner, M. On the simultaneity problem in the aid and growth debate. J. Appl. Econometr. 2013, 28, 126-150. [CrossRef] 
3. Morrison, K.M. What can we learn about the "Resource Curse" from foreign aid? World Bank Res. Obs. 2012, 27, 52-73. [CrossRef]

4. Zhupankin, A.; Tussupova, K.; Berndtsson, R. Could changing power relationships lead to better water sharing in Central Asia? Water 2017, 9, 139. [CrossRef]

5. Jalilov, S.-M.; Varis, O.; Keskinen, M. Sharing benefits in transboundary rivers: An experimental case study of Central Asian water-energy-agriculture nexus. Water 2015, 7, 4778-4805. [CrossRef]

6. Bai, M.; Zhou, S.; Zhao, M.; Yu, J. Water use efficiency improvement against a backdrop of expanding city agglomeration in developing countries-A case study on industrial and agricultural water use in the Bohai Bay Region of China. Water 2017, 9, 89. [CrossRef]

7. Tavares, J. Does foreign aid corrupt? Econ. Lett. 2003, 79, 99-106. [CrossRef]

8. Young, A.T.; Sheehan, K.M. Foreign aid, institutional quality, and growth. Eur. J. Polit. Econ. 2014, 36, 195-208.

9. Feder, G.; Umali, D. The adoption of agricultural innovations: A review. Technol. Forecast. Soc. Chang. 1993, 43, 215-239. [CrossRef]

10. Diederen, P.; Meijl, H.V.; Wolters, A. Modernisation in agriculture: What makes a farmer adopt an innovation? IJARGE 2003, 2, 328-342. [CrossRef]

11. Potts, P.W. Experience in the transfer of handpump technology to less developed countries. J. Technol. Transf. 1984, 8, 35-46. [CrossRef]

12. Oberkircher, L. On pumps and paradigms: Water scarcity and technology adoption in Uzbekistan. Soc. Nat. Resour. 2011, 24, 1270-1285. [CrossRef]

13. Kazbekov, J.; Wegerich, K.; Yakubov, M.; Musayev, S. Project owners-Overlooked factors of uncertainty in the example of water infrastructure improvement project. Environ. Sci. Policy 2015, 53, 236-245. [CrossRef]

14. Dukhovny, V.; Sokolov, V.; Ziganshina, D. The role of donors in adressing water problems in Central Asia. Irrig. Drain. 2015, 65, 79-85. [CrossRef]

15. Sunding, D.; Zilberman, D. The agricultural innovation process: Research and technology adoption in a changing agricultural sector. Handb. Agric. Econ. 2001, 1, 207-261.

16. Askarov, Z.; Doucouliagos, H. Development aid and growth in transition countries. World Dev. 2016, 66, 383-399. [CrossRef]

17. Radosevic, S. Regional innovation systems in Central and Eastern Europe: Determinants, organizers and alignments. J. Technol. Transf. 2002, 27, 87-96. [CrossRef]

18. Ayres, C.E. The Theory of Economic Progress; University of North Carolina Press: Chapel Hill, NC, USA, 1944.

19. Ayres, C.E. Toward A Reasonable Society: The Values of Industrial Civilization; University of Texas Press: Austin, TX, USA, 1961.

20. Foster, J.F. Syllabus for problems of modern society: The theory of institutional adjustment. J. Econ. Issues 1981, 15, 929-935.

21. Bush, P.D. The Structural Characteristics of a Veblen-Ayres-Foster-Defined Institutional Domain. J. Econ. Issues 1983, 17, 35-66. [CrossRef]

22. Bush, P.D. The theory of institutional change. J. Econ. Issues 1987, 21, 1075-1116. [CrossRef]

23. Hayden, F.G. Policymaking for a Good Society: The Social Fabric Matrix Approach to Policy Analysis and Program Evaluation; Springer Science \& Business Media: New York, NY, USA, 2006.

24. Veblen, T. The limitations of marginal utility. J. Polit. Econ. 1909, 17, 620-636. [CrossRef]

25. Elsner, W. Microeconomics of Interactive Economies: Evolutionary, Institutional, and Complexity Perspectives; Edward Elgar Publishing: Northampton, MA, USA, 2012.

26. Valentinov, V. Veblen and instrumental value: A systems theory perspective. J. Econ. Issues 2013, 47, 673-688. [CrossRef]

27. Hielscher, S.; Pies, I.; Valentinov, V. How to foster social progress: An ordonomic perspective on progressive institutional change. J. Econ. Issues 2012, 46, 779-797. [CrossRef]

28. Elsner, W. The theory of institutional change revisited: The institutional dichotomy, its dynamic, and its policy implications in a more formal analysis. J. Econ. Issues 2012, 46, 1-44. [CrossRef]

29. Klein, P.A. Instrumental valuation in a democratic society. In Institutional Economics and the Theory of Social Value: Essays in Honor of Marc R. Tool; Springer Science \& Business Media: New York, NY, USA, 2012.

30. Tool, R. The Discretionary Economy: A Normative Theory of Political Economy; Transaction Publishers: New Brunswick, NJ, USA; London, UK, 2001. 
31. Commons, J.R. Institutional Economics: Its Place in Political Economy; Transaction Publishers: New Brunswick, NJ, USA; London, UK, 1989.

32. Valentinov, V. Mapping the third sector in John R. Commons' typology of transactions. J. Econ. Issues 2009, 43, 917-930. [CrossRef]

33. Bromley, D. Sufficient Reason: Volitional Pragmatism and the Meaning of Economic Institutions; Princeton University Press: Princeton, NJ, USA, 2009.

34. Bromley, D.; Anderson, G. Vulnerable People, Vulnerable States: Redefining the Development Challenge; Routledge: Oxon, UK, 2012.

35. Ramstad, Y. The institutionalism of John R. Commons: Theoretical foundations of a volitional economics. Res. Hist. Econ. Thought Methodol. 1990, 8, 53-104.

36. Valentinov, V. The economics of the nonprofit sector: Insights from the institutionalism of John R. Commons. Soc. Sci. J. 2012, 49, 545-553. [CrossRef]

37. Chaddad, F.; Valentinov, V. Agency costs and organizational architecture of large corporate farms: Evidence from Brazil. Int. Food Agribus. Man. Rev. 2017, 20, 201-220. [CrossRef]

38. Luhmann, N. Zweckbegriff und Systemrationalität; Suhrkamp: Frankfurt am Main, Germany, 1999.

39. Thompson, S.; Valentinov, V. The neglect of society in the theory of the firm: A systems theory perspective. Camb. J. Econ. 2017. [CrossRef]

40. Valentinov, V. From equilibrium to autopoiesis: A Luhmannian reading of Veblenian evolutionary economics. Econ. Syst. 2015, 39, 143-155. [CrossRef]

41. Pomfret, R. State-directed diffusion of technology: The mechanization of cotton harvesting in Soviet Central Asia. J. Econ. Hist. 2002, 62, 170-188.

42. Keller, S. The puzzle of manual harvest in Uzbekistan: Economics, status and labour in the Khrushchev era. Cent. Asia Surv. 2015, 34, 296-309. [CrossRef]

43. Cocks, P. The Role of the Party in Soviet Science and Technology Policy; Stanford University: Stanford, CA, USA, 1976.

44. Gleason, G. Between Moscow and Tashkent: The Politics of the Uzbek Cotton Production Complex. Ph.D. Thesis, University of California, CA, USA, 1984.

45. Dearden, J.; Ickes, B.W.; Samuelson, L. To innovate or not to innovate: Incentives and innovation in hierarchies. Am. Econ. Rev. 1990, 80, 1105-1124.

46. Berliner, J.S. The Innovation Decision in Soviet Industry; MIT Press Books: Cambridge, MA, USA, 1976.

47. Veblen, T. The instinct of Workmanship; Augustus M. Kelley: New York, NY, USA, 1964.

48. Yamaswari, I.A.C.; Kazbekov, J.; Lautze, J.; Wegerich, K. Sleeping with the enemy? Capturing internal risks in the logical framework of a water management project. Int. J. Water Resour. Dev. 2015, 32, 116-134. [CrossRef]

49. Mehta, L. Politics and Poetics of Water: Naturalising Scarcity in Western India; Orient Longman: New Delhi, India, 2005.

50. Williams, R.; Edge, D. The social shaping of technology. Res. Policy 1996, 25, 865-899. [CrossRef]

51. Oberkircher, L.; Hornidge, A.K. "Water is life"-Farmer rationales and water saving in Khorezm, Uzbekistan: A lifeworld analysis. Rural Sociol. 2011, 76, 394-421. [CrossRef]

52. Dewey, J. Human Nature and Conduct: An Introduction to Social Psychology; Carlton House: New York, NY, USA, 1922.

53. Bekchanov, M.; Lamers, J.P.; Martius, C. Pros and cons of adopting water-wise approaches in the lower reaches of the Amu Darya: A socio-economic view. Water 2010, 2, 200-216. [CrossRef]

54. Street, J.H. The institutionalist theory of economic development. In Evolutionary Economics; Sharpe: Armonk, NY, USA, 1988.

55. Soliev, I.; Wegerich, K.; Kazbekov, J. The costs of benefit sharing: Historical and institutional analysis of shared water development in the Ferghana Valley, the Syr Darya basin. Water 2015, 7, 2728-2752. [CrossRef]

56. World Country Study Guide. Strategic Information and Developments. In Uzbekistan Country Study Guide; International Business Publications: Washington, DC, USA, 2015.

57. Howard, K.W.; Howard, K.K. The new "Silk Road Economic Belt" as a threat to the sustainable management of Central Asia's transboundary water resources. Environ. Earth Sci. 2016, 75, 976. [CrossRef]

58. World Bank Group. World Bank Development Indicators 2016; International Bank for Reconstruction and Development/The World Bank: Washington, DC, USA, 2016. 
59. Acemoglu, D.; Cantoni, D.; Johnson, S.; Robinson, J.A. The consequences of radical reform. Am. Econ. Rev. 2011, 101, 3286-3307. [CrossRef]

60. Kopsidis, M.; Bromley, D. The French revolution and German industrialization: Dubious models and doubtful causality. J. Institut. Econ. 2015, 12, 161-190. [CrossRef]

61. Oughton, C.; Landabaso, M.; Morgan, K. The regional innovation paradox: Innovation policy and industrial policy. J. Technol. Transf. 2002, 27, 97-110. [CrossRef]

62. Rodrik, D. When ideas trump interests: Preferences, worldviews, and policy innovations. J. Econ. Perspect. 2014, 28, 189-208. [CrossRef]

63. Chambers, R. Ignorance, error and myth in South Asian irrigation: Critical reflections on experience. Water Altern. 2013, 6, 154-167.

64. Huppert, W. Rent-seeking in agricultural water management: An intentionally neglected core dimension? Water Altern. 2013, 6, 265-275.

65. Jensen, K.M. Swimming against the current: Questioning development policy and practice. Water Altern. 2013, 6, 276-283.

66. Levine, G. The search for understanding irrigation-Fifty years of learning. Water Altern. 2013, 6, $259-264$.

(C) 2017 by the authors. Licensee MDPI, Basel, Switzerland. This article is an open access article distributed under the terms and conditions of the Creative Commons Attribution (CC BY) license (http:/ / creativecommons.org/licenses/by/4.0/). 